\title{
Attitudes toward safety and its affecting factors in Sanandaj emergency medical services staffs, in 2017
}

\author{
Gavili $\mathbf{H}^{1}$, Fathi $\mathbf{M}^{2}$, Zarezadeh $\mathbf{Y}^{3}$, Roshani $\mathrm{D}^{4}$, Yaghubi $\mathbf{M}^{5}$ \\ 1. Student Research Committee, Kurdistan University of Medical Sciences, Sanandaj, Iran. \\ 2. Assistant Professor of Nursing, Clinical Care Research Center, Research Institute for Health Development, Kurdistan \\ University of Medical Sciences, Sanandaj, Iran. \\ 3. Associate Professor of Medical Education, Social Determinants of Health Research Center, Research Institute for Health \\ Development, Kurdistan University of Medical Sciences, Sanandaj, Sanandaj, Iran. \\ 4. Associate Professor of Biostatistics, Social Determinants of Health research Center, Research Institute for Health \\ Development, Kurdistan University of Medical Sciences, Sanandaj, Iran, Sanandaj, Iran. \\ 5. Instructor of Nursing, Clinical Care Research Center, Kurdistan University of Medical Sciences, Sanandaj, Iran, \\ (Corresponding Author) Tel: +98-87-33664658, Email: mokhtaryaghobi@yahoo.com
}

\begin{abstract}
:
Background and Aim: Safety is one of the important subjects in the pre-hospital settings. Determination and evaluation of safety attitudes of the emergency staff is the first step toward improving the safety of the staff and patients. In this study, we investigated safety attitudes and the factors affecting safety such as error and accident history, during mission, in the last year, in the staff of emergency medical services in Sanandaj.

Material and Methods: This was a cross-sectional descriptive study. We used census method. Study population included personnel of emergency medical services (72 people). We used a questionnaire for data collection. SPSS version 20 software was used for data analysis. Pearson correlation coefficient, Spearman correlation coefficient and chi-square test were used to determine the relationship between the variables and the safety attitudes.

Results: Based on the findings of this study, the safety attitudes of the emergency medical staff were significantly at a low level (mean: 3.11, $\mathrm{p}= \pm 0 / 435$ ). Six dimensions of safety attitudes, including the cooperative atmosphere in the organization, safety climate in the organization, perceptual management, and job status had significant relationship with demographic characteristics. Job satisfaction criteria and stress recognition showed no significant relationship with demographic characteristics.

Conclusion: The results of this study showed that the safety attitudes of the emergency medical staff towards safety were significantly at a low level. Therefore education in order to improve the attitudes of the emergency medical staff is necessary. We recommend inclusion of safety attitudes conceot in educational programs for emergency medical staff.
\end{abstract}

Key words: Emergency Medical Services, Safety, Attitude.

Recevied: Aug 2, 2018

Accepted:Nov 13, 2018

How to cite the article: Gavili H, Fathi M, Zarezadeh Y, Roshani D, Yaghubi M. Attitudes toward safety and its affecting factors in Sanandaj emergency medical services staffs, in 2017. SJKU 2019; 24 (1): 134-145.

Copyright (C) 2019 the Author (s). Published by Kurdistan University of Medical Sciences. This is an open access article distributed under the terms of the Creative Commons Attribution-Non Commercial License 4.0 (CCBY-NC), where it is permissible to download, share, remix, transform, and buildup the work provided it is properly cited. The work cannot be used commercially without permission from the journal. 


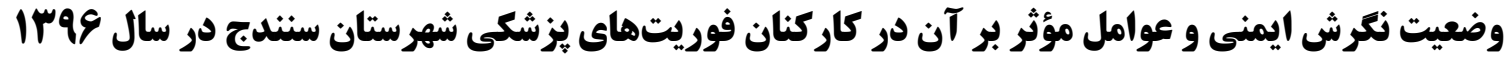

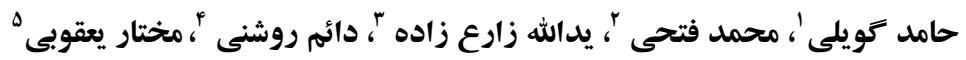

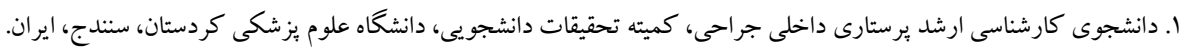

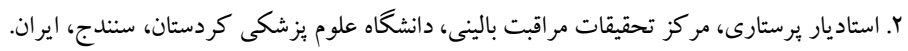

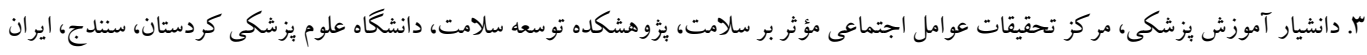

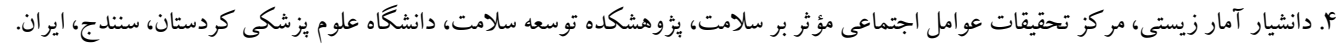

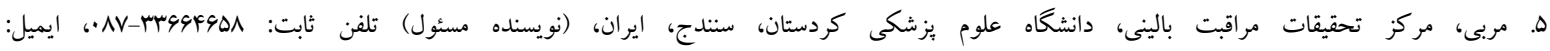
mokhtaryaghobi@yahoo.com

\section{جكيده}

زمينه و هدف: يكى از مباحث مهم در اورزانس بيش بيمارستانى موضوع ايمنى است. قدم اول جهت ارتقاء ايمنى كاركنان و

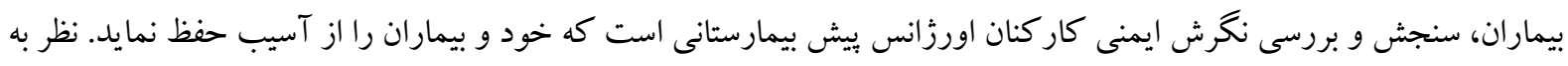

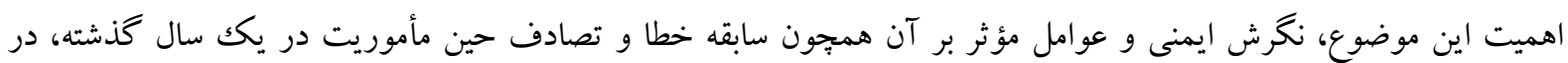

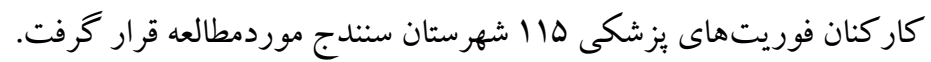
روش بررسى: اين مطالعه توصيفى تحليلى_مقطعى در سال وهץ| انجام شده است. جامعه مورد مطالعه كار كنان فوريتهاى

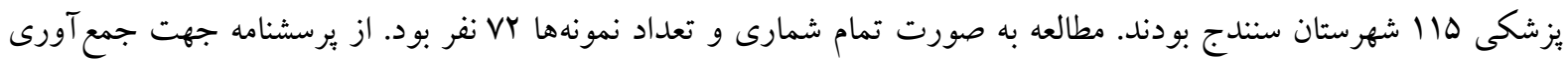

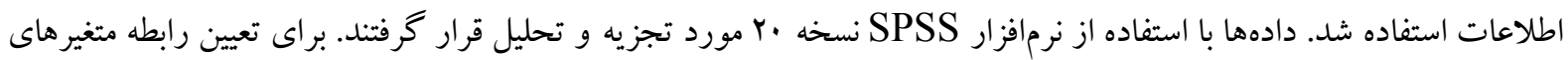

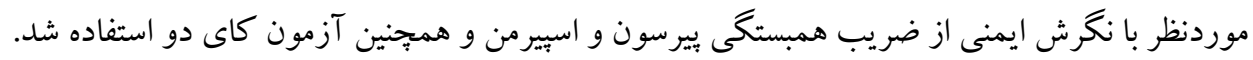

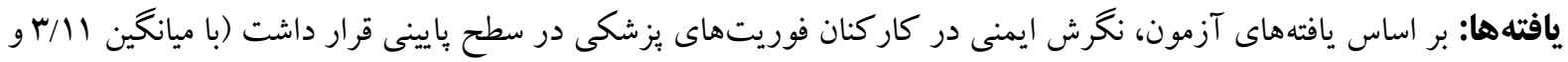

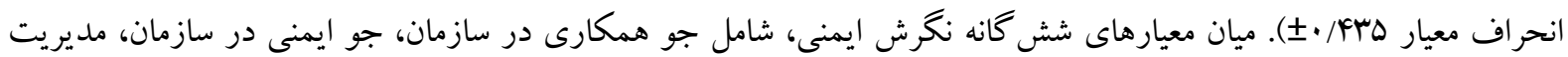
ادراكات، وضعيت شغلى با خصوصيات دمو گرافيك ارتباط معنىدار وجود داشت. مابين معيارهاى رضايت شغلى و شناخت

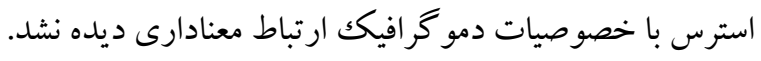

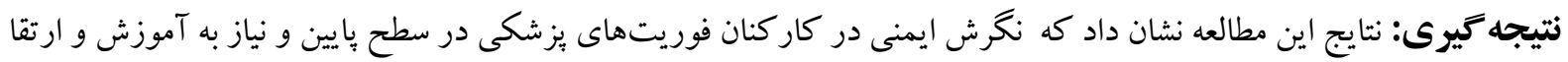

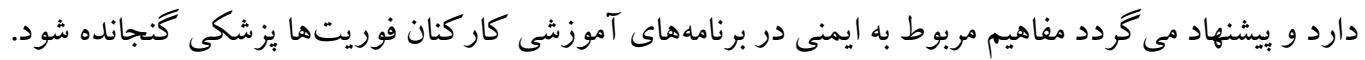

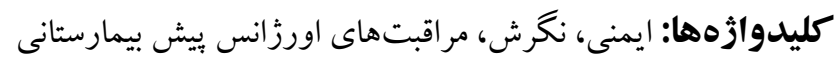

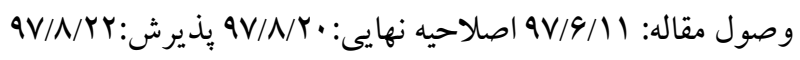


خدمات اوليه(Y)(V)(Y) با اين وجود، امروزه در مراقبت ايمن از بيمار در سازمانهاى ارائهدهنده خدمات سلامت مقدمه مخاطراتى وجود دارد و حدود Y/9 تا 19/9 درصد از بيماران بسترى تحت تأثير عوارض جانبى همجِون خطاهاى دارويى، عفونت يا سقوط هستند(9). در مطالعه ويور' و

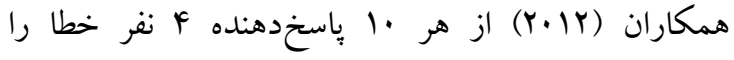
كزارش كرده بودند(·(1). با اين ديد مىتواند كفت كه با با مشاركت كاركنان، گزارش وقايع بهطور فعال و مؤثر مورد تجزيه وتحليل عليتى قرارگرفته و نتايج آن در رفع زمينه هاى خطا و اصلاح فرآيندهاى مربوطه مورداستفاده قرار مى گيرند. در اين ميان استدلال بالينى و تصميم گيرى بهعنوان مهمترين موضوع در ارتباط با ايمنى بيمار در

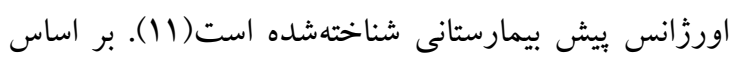

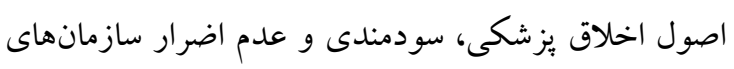
ارائهدهنده خدمت موظف هستند به منظور افزايش سودمندى و كاهش ضررها و خطرهاى احتمالى، ايمنى را به عنوان يكك اصل مورد توجه قرار دهند(YI). در اينجاست كه نقش مهم ايمنى مشخص مى شود و به يك نتيجه مىرسيم كه براى ايمنتر كردن محيط كار و كاهش خطا و هزينهاى ناشى از آنها بايستى به فرهنگك ايمنى توجه بيشترى شود تا بتوانيم بهطور ريشهاى و اصولى با خطاها

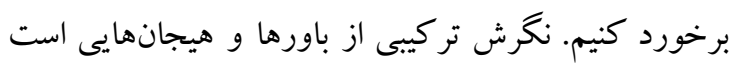

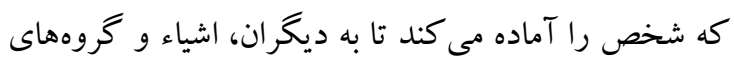

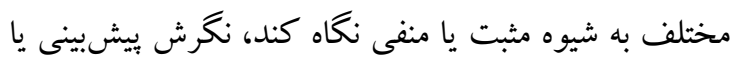

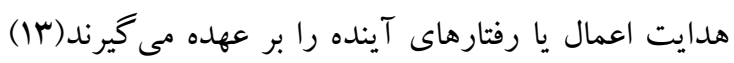
و راهحلى نسبت به يكك موضوع، از طريق تفكر و يا احساس است(F). يكى از حقايق در مورد انسانها كه بهصورت وسيع مورد يذيرش قرار كرفته، اين است كه هيج دو فردى شبيه همديخر نيستند جه از نظر ظاهرى (ساختار بدنى، قد، وزن، رنگَك و ...) و جهه جنبه انتزاعى (مانند هوش، نخرش، شخصيت، رفتار و امثال آن). بسيارى از افراد نگرش فردى خود را بهعنوان رفتار مىيندارند. هر جند كه اين دو بهطور

${ }^{1}$ Weaver, Matthew D et al. 


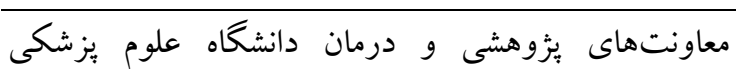

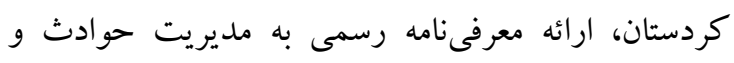
فوريتهاى بز شكى كردستان، اخذ رضايت آكاهانه از

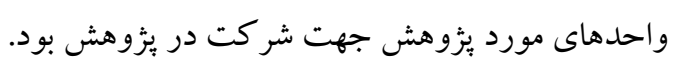

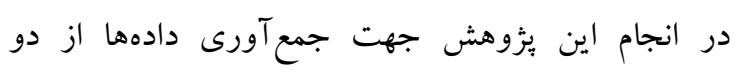
يرسشنامه مشخصات فردى محقق ساخته شامل اطلاعات

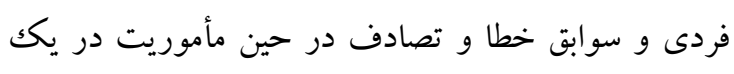

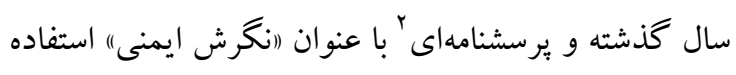

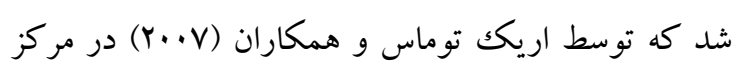

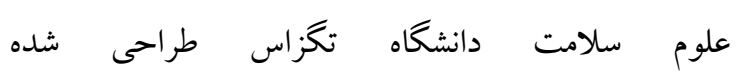

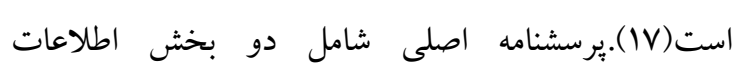

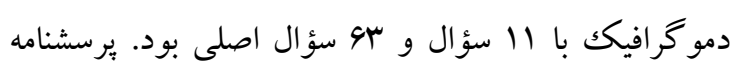
بومى سازى شده در دو بخش اطلاعات دمو كرافيك شامل

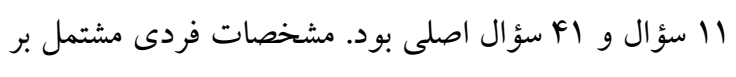
سؤالاتى جهت ارزيابى برخى از متغيرها از جمله سن،

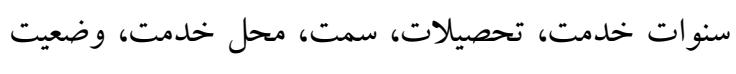

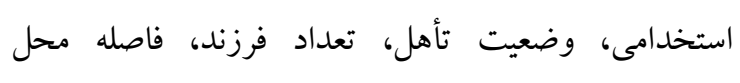

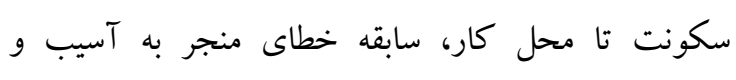
تصادف با آمبولانس در حين مأموريت در يكك سال

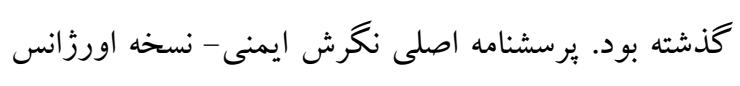
بيش بيمارستانى داراى به سؤال بود كه .ب سؤال در 4

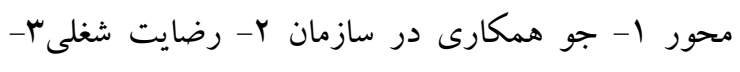

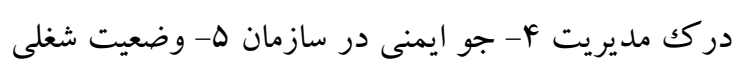

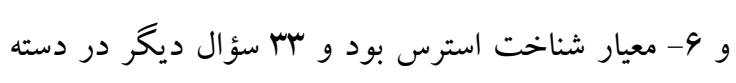

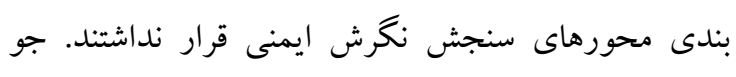

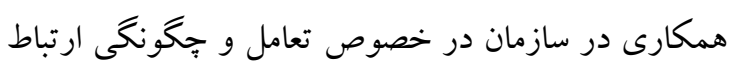

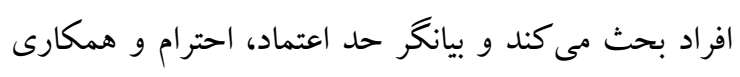

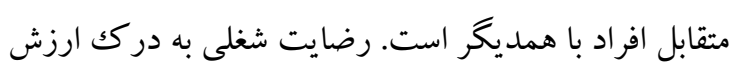

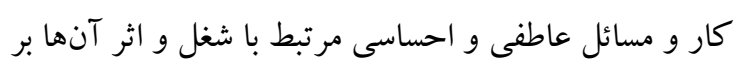

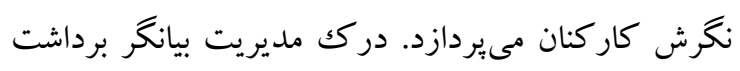

${ }^{2}$ The Safety Attitudes Questionnaire-Ambulatory Version
مستقيم يا غيرمستقيم به هم وابسته هستند و به معنى آن است

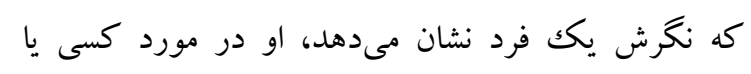

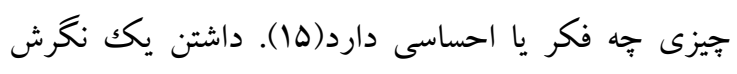
مثبت براى موفقيت در هر حوزهاى ضرورى است فئس (19).

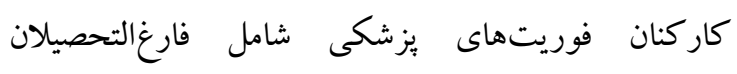

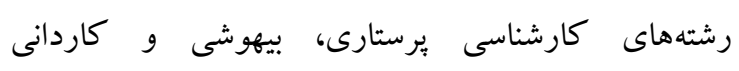

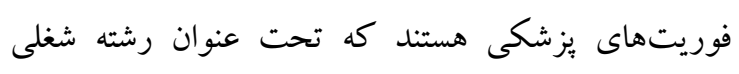

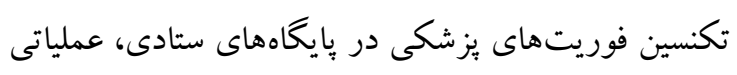

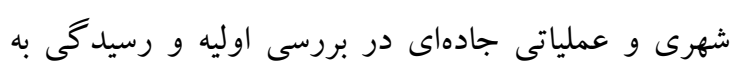

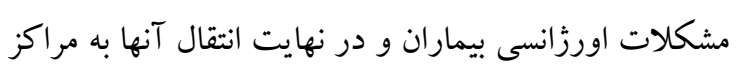
درمانى مرتبط، مشغول به فعاليت هستند. با توجه به اهميت

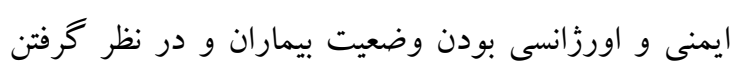
اين موضوع كه اولين كسانى كه بر بالين بيمار حضور

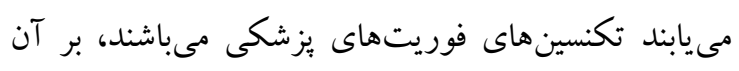

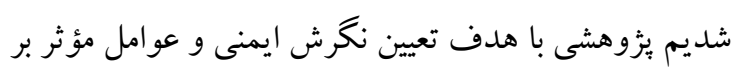

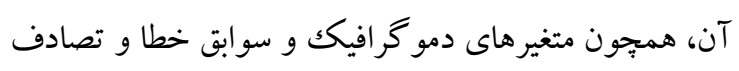
در حين مأموريت در يكك سال كذشته را در كاركنان فوريتهاى بزشكى ها 11 شهرستان سنندج انجام دهيم.

\section{روش بر رسى}

اين مطالعه، يُزوهشى توصيفى - تحليلى (مقطعى) بود. جامعه

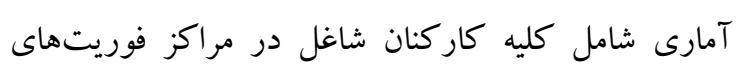

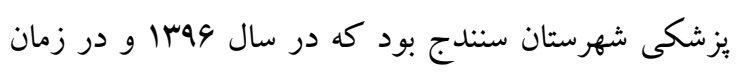

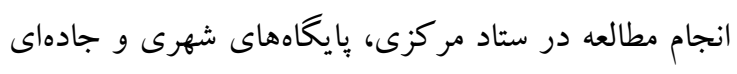

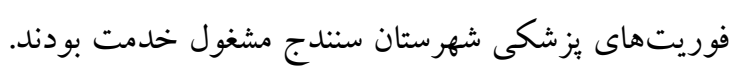

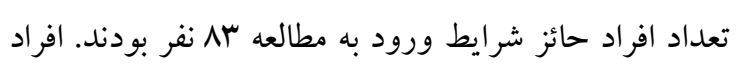
مورد مطالعه شامل تمامى كار كنانى بود كه در وضعيت هاى

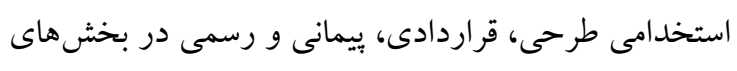

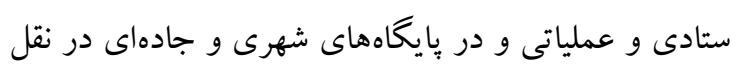
و انتقال بيماران و مصدومين نقش داشته بودند. كاركنان ونان

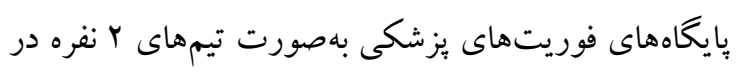

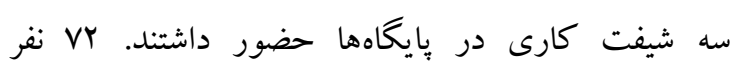

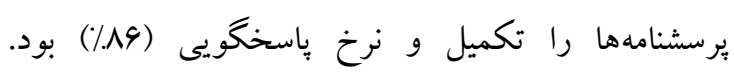

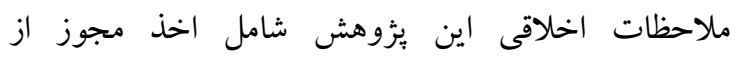


مسار وضعيت نكرش ايمنى ....

يُوهشگ و و يا عدم تمايل به تكميل آن از مطالعه حذف

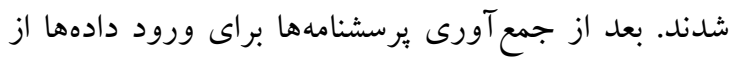

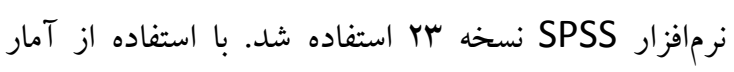

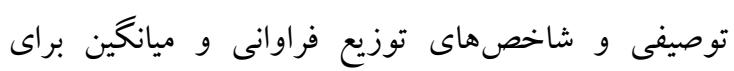

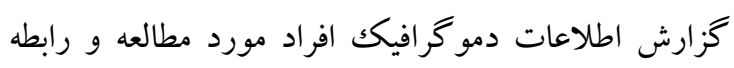
آن با نخرش ايمنى استفاده شد. همجنين براى تعيين رابطه

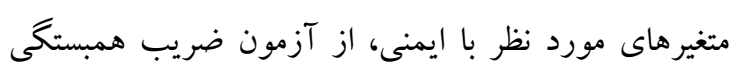
ييرسون و اسييرمن و همجنين آزمون كاى دو استفاده شد.

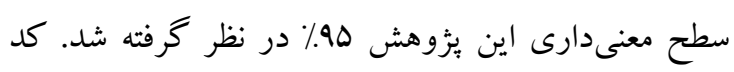

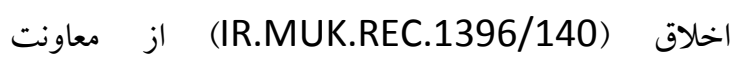

$$
\text { ئزوهشى دريافت گرديد. }
$$

\section{يشنهادها براى يزوهشهاى بعدى:}

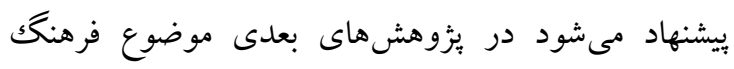

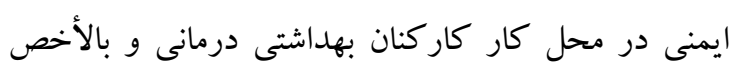

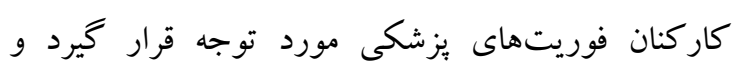

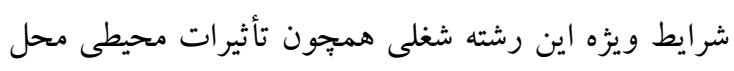

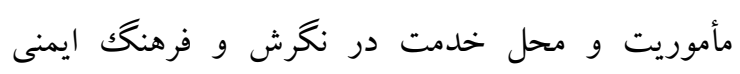
كار كنان مورد توجه قرار گيرد.

يافتهها

بر اساس نتايج اين مطالعه كه بر روى Vr يرسشنامه تكميل

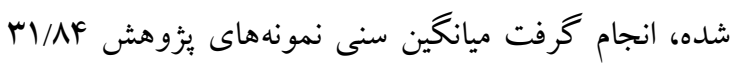

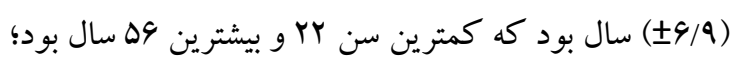
و گروه سنى هو تا اس سال داراى بيشترين فراوانى بود.

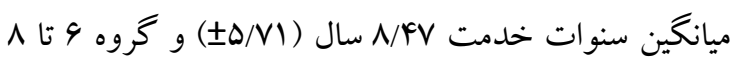

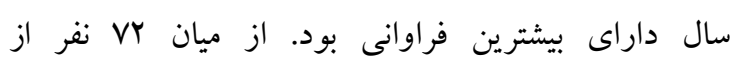

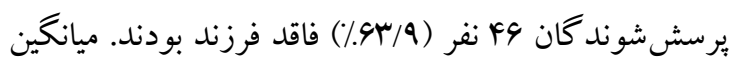

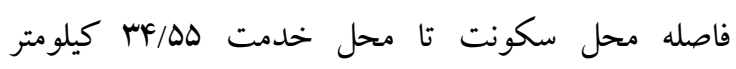

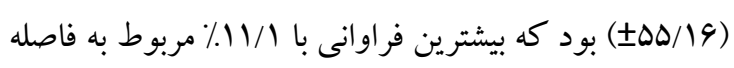

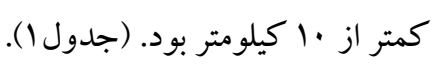

كاركنان از بشتيبانى مديريت در ارائه منابع كافى جهت التهن ايجاد شرايط ايمن هست. جو ايمنى در سازمان؛ بيانكر

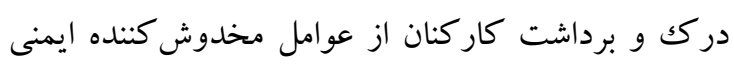

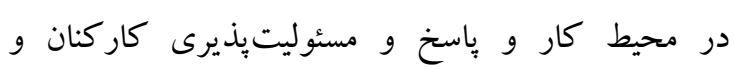

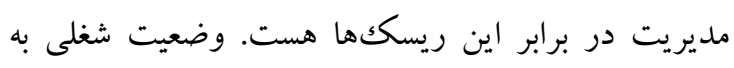

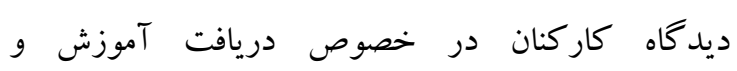

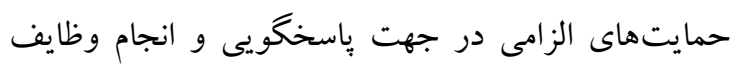
كارى اشاره دارد. شناخت استرس؛ به آكاهى كاركنان از داز

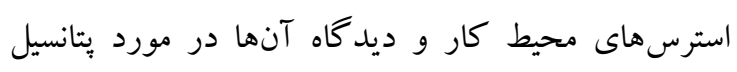
تأثير اين عوامل در مختل كردن عملكردشان مى يردازد (A).

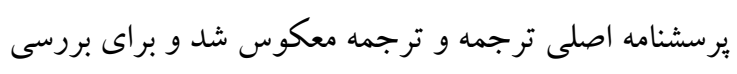

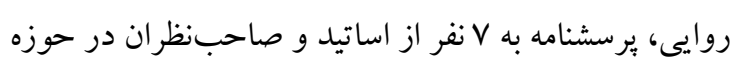

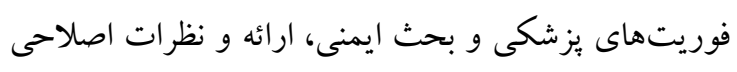

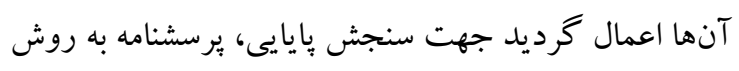

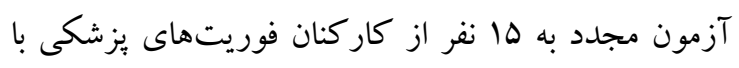

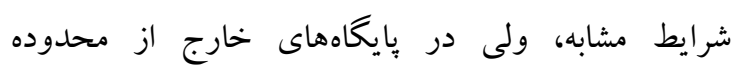

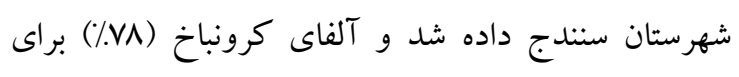

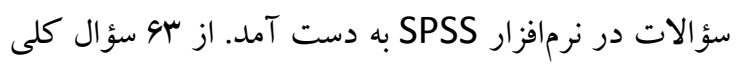

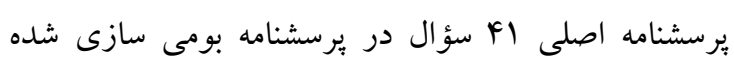

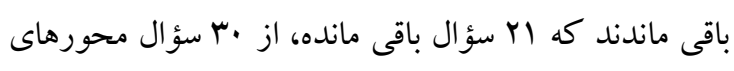

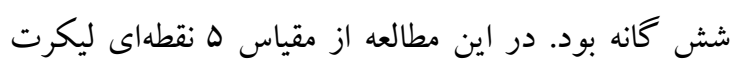

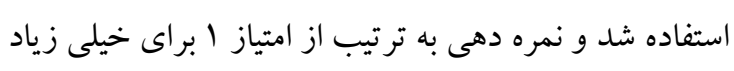

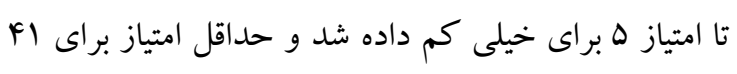

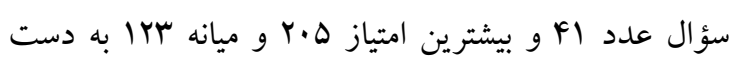

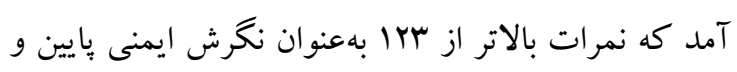

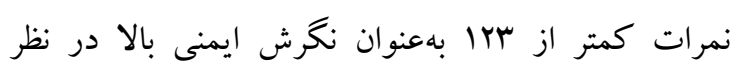

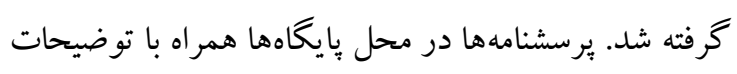
لازم توسط يُوهشخر تحويل كاركنان داده شد. معيار خروج از مطالعه عدم تمايل به همكارى در تكميل برسشنامه تُونه

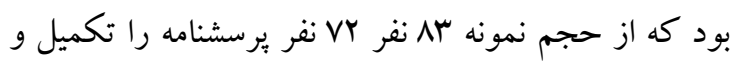
11 نفر به دليل عدم حضور در محل كار در زمان حضور 


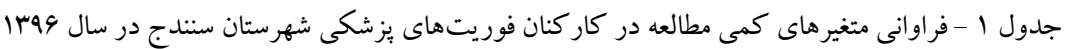

\begin{tabular}{|c|c|c|c|c|}
\hline انحر اف معيار & ميانگين & حداكثر & حداقل & متغيرها \\
\hline $9 / 9$ & $M I / \Lambda F$ & $\Delta 9$ & rr & سن (سال) \\
\hline$\Delta / V I$ & $\Lambda / F V$ & ro &.$\mu$ & سنوات (سال) \\
\hline$\cdot / N+1$ &.$/ 4 \wedge$ & $r$ & · & تعداد فرزند (نفر) \\
\hline$\Delta \Delta / 19$ & $M F / \Delta Q$ & ro. &.$/ \Delta$ & فاصله تا محل كار (كيلومتر) \\
\hline
\end{tabular}

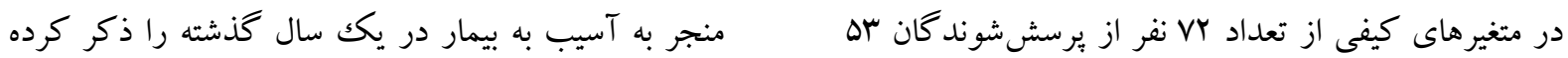

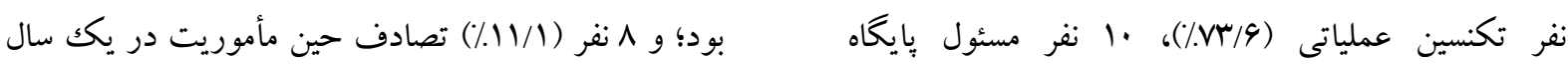

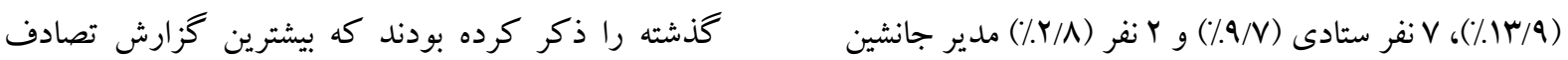

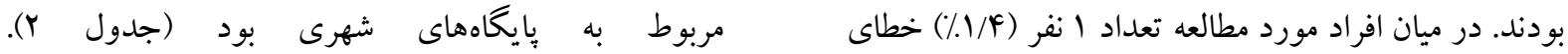

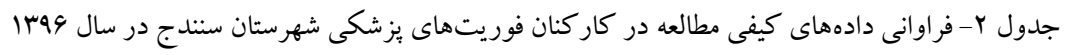

\begin{tabular}{|c|c|c|c|c|c|}
\hline انحراف معيار & 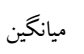 & درصد & تعداد (n) & جزئيات متغير هاى دمو كرافيك & تغيرهاى دمو گر افيك \\
\hline- & - & $r / \Lambda$ & r & دييلم & \multirow{3}{*}{ تحصيلات } \\
\hline .rQAYA & $r / \cdot r$ & $r V / \Delta$ & rV & كاردان & \\
\hline.$/ D 19 T F$ & $r / l v$ & $\Delta q / v$ & rr & كارشناس & \\
\hline - /FFGYG & $r / r$ &.$N \Delta$ & $\Delta r$ & عملياتى & \multirow{4}{*}{ سمت } \\
\hline -rranV & $r / 19$ & $1 \% / 9$ & 1. & مسئول بايخاه & \\
\hline$. / \mu 1 . k F$ & $r / N \Lambda$ & $r / \Lambda$ & r & مدير جانشين & \\
\hline . NTrFV & r/qr & $\Lambda / r$ & $\checkmark$ & ستادى س & \\
\hline$\cdot / \varepsilon q \cdot \Delta \Lambda$ & $r / \cdot \Lambda$ & $\kappa \mu / 1$ & r & بإيكاه شهرى & \multirow{3}{*}{ محل خدمت } \\
\hline . MFrVF & $r / 19$ & $\kappa \psi / F$ & rr & بِايكاه جادهاى & \\
\hline.$/ 4 q \cdot \Delta \Lambda$ & $r / M$ & $\mid r / \Delta$ & 9 & ستاد مر كزى & \\
\hline$\cdot r \cdot F \Delta r$ & $r / .1$ & $19 / 4$ & if & طرحى & \multirow{4}{*}{ وضعيت شغلى } \\
\hline.$/ Q 1 F V$. & $r / .9$ & $\Delta 1 / F$ & rv & ق ق قراردادى & \\
\hline$\cdot /$ /reqka & $r / 99$ & $k / r$ & $r$ & بيمانى & \\
\hline ./rY9N9 & $r / r$. & $\cdot / r \Delta$ & M & 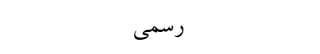 & \\
\hline.$/ 49914$ & $r / . r$ & $r F / V$ & ro & 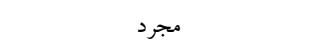 & \multirow{2}{*}{ تأهل } \\
\hline$\cdot / r M \cdot r$ & $r / M V$ & $90 / r$ & pv & متأهل & \\
\hline- & - & $1 / 4$ & 1 & داراى سابقه خطا منجر به آسيب & \multirow{2}{*}{ سابقه خطا منجر به آسيب به بيمار } \\
\hline- & - & $9 / / 9$ & vi & فاقد سابقه خطا منجر به آسيب & \\
\hline / TANFV & $r / \Gamma \Lambda$ &.$/ 1$ & $\wedge$ & داراى سابقه تصادف در حين خدمت & \multirow{2}{*}{ سابقه تصادف در حين مأموريت } \\
\hline - afartr & $r / .9$ & $\cdot / \wedge 9$ & $a q$ & فاقد سابقه تصادف در حين خدمت & \\
\hline
\end{tabular}


در خصوص تعداد فرزند، افراد داراى يكك فرزند ميانخين نكرش ايمنى V/

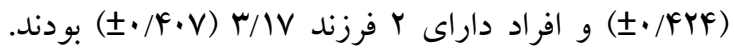

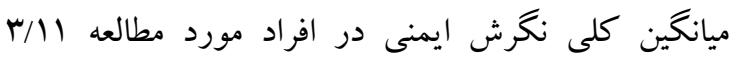

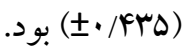
بر اساس يافتهاى آزمون، از ميان معيارهاى شش كانه نغرش ايمنى، معيار جو همكارى در سازمان معنادار و

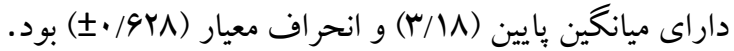

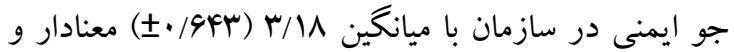

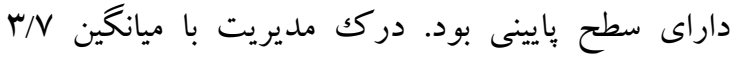

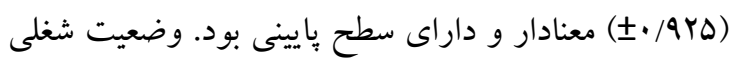

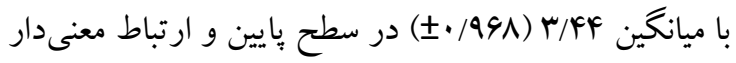

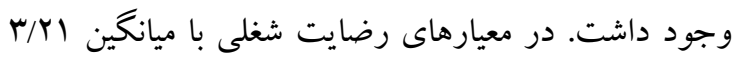

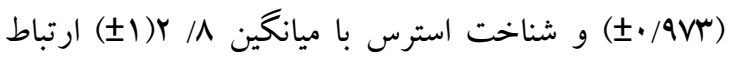

$$
\text { معنادارى ديده نشد (جدولr). }
$$

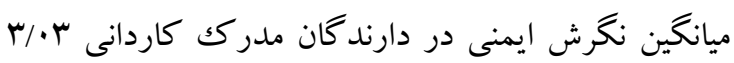

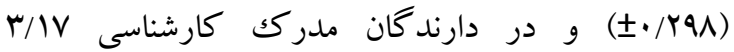

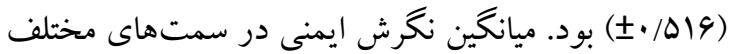

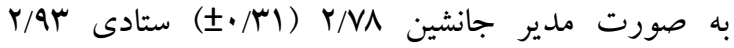
( (I) بود و بر اساس محل خدمت افراد مورد مطالعه

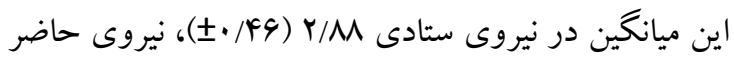

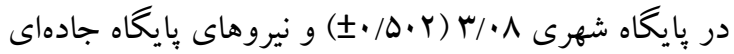

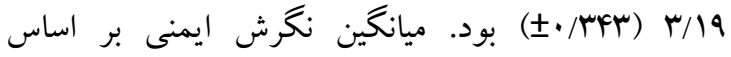

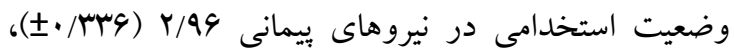

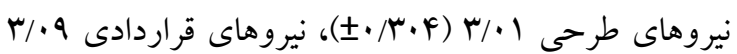
(I/D/f)

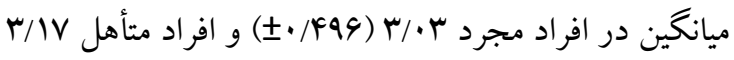
بود (

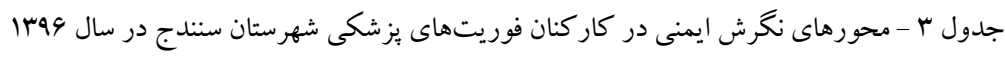

\begin{tabular}{|c|c|c|c|c|c|}
\hline انحر اف معيار & معنادارى & ميانگين & تعداد بِاسخ دهنگَان به كل سؤ الات محورها & رتبه & محورهاى نخرش ايمنى \\
\hline . /9YDGI & $\cdot \%$ & $r / N$. & vr & 1 & مديريت ادراكات \\
\hline.$/ 99 \Lambda$. & $\cdot / \cdot$ & $r / F q$ & 99 & $r$ & رضايت شغلى \\
\hline $.19 Y 1$ &.$/ .1 V$ & $r / M$ & vi & f & جو همكارى \\
\hline .1944 & $.1 \cdot 11$ & $r / M$ & 91 & $r$ & جو ايمنى \\
\hline.$/ 9 V \pi$ & .1 .94 & $r / r$ & vi & $\Delta$ & وضعيت شغلى \\
\hline 1 & .11 .9 & $r / \Lambda$. & $v$. & 9 & تشخيص استرس \\
\hline
\end{tabular}

كارگران جوانتر داشتهاند(1)). در مطالعه رضايى و

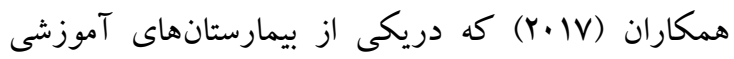
نتايج مطالعه نشان داد كه نخرش ايمنى در كاركنان

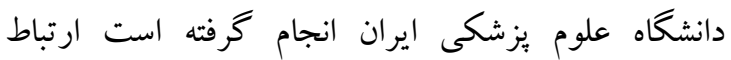
فوريتهاى يزشكى 110 شهرستان سنندج در سطح بايينى

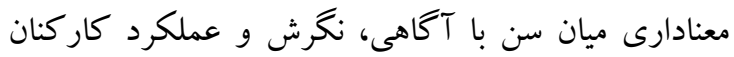

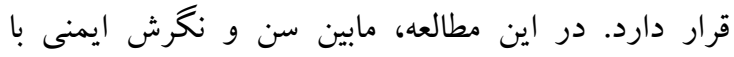

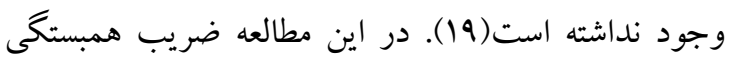

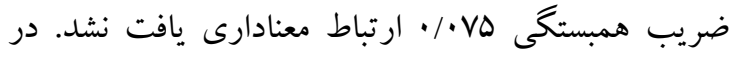
مثبت (هVV/•) بوده است. در اين مطالعه رابطه سنوات

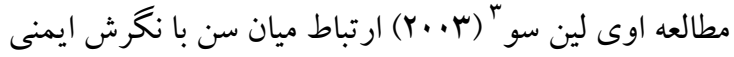

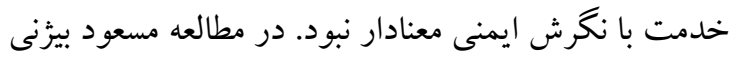
در كاركران ساختمانى هنگك كنگك مثبت بوده است و و (Y.19) مابين سابقه كار و ايمنى در كارشناسان جهاد كارگران مسنتر نخرش ايمنى مثبت و بهترى نسبت به به

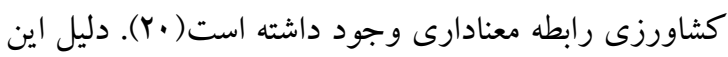


مابين حالتهاى مختلف وضعيت استخدامى طرحى، قراردادى، ييمانى و رسمى در افراد مورد مطالعه با نكرش ايمنى، تفاوت معنادارى وجود نداشت با اين وجود،

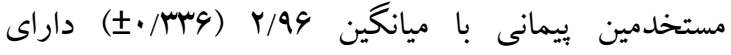
بالاترين و مستخدمين رسمى با .ب/ץ (צץ//さ) داراى پايين ترين ميانگين نخرش ايمنى بودند. در مطالعه عفراوى و همكاران (Y.19) رابطه ميان وضعيت استخدامى با نكرش ايمنى در كار كنان بهداشتى و درمانى بخشهاى ويزه مراكز درمانى آموزشى و غير آموزشى اهواز معنادار نبود(^). مى توان نتيجه گرفت كه كار كنان رسمى در نهايت وضعيت استخدامى خود هستند و كاركنان بيمانى براى ارتقاء به وضعيت رسمى داراى تلاش بيشترى براى بهبود وضعيت كارى خود هستند. مابين وضعيت تأهل افراد موردمطالعه با نخرش ايمنى، تفاوت معنادارى وجود نداشت، درحالى كه افراد مجرد با

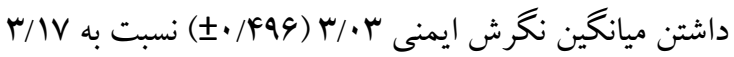
افراد متأهل داراى نخرش ايمنى بالاترى بودند. در مطالعه امينى و همكاران (Y/Y) فرهنگك ايمنى در كاركنان متأهل كارخانه هاى توليد مواد شوينده نسبت به افراد مجرد بالاتر و معنادار بوده است(سY). در مطالعه فضلى و قهرمانى (Y) (Y) ميان تأهل و فرهنگك ايمنى در كاركنان شركتهاى توليدى شهرستان اروميه رابطه معنادارى ديده نشده است(YY). مىتوان نتيجه گرفت تأهل و ملزومات زندكى مشترك و بازتاب آن در محل كار با توجه به خود گردان بودن بايخاههاى فوريتهاى بزشكى، در نخرش ايمنى كاركنان تأثير مثبت دارد؛ در اين ميان رابطه مثبت متغير سن با تأهل و هر دو با نخرش ايمنى، قابل توجه است. ميان تعداد فرزند و نخرش ايمنى ارتباط معنادارى وجود

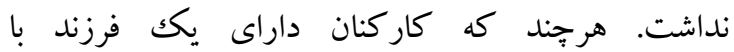

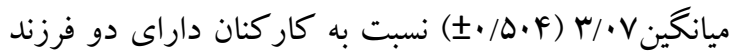

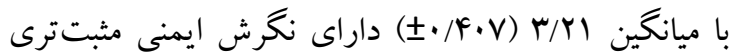
بودند. در مطالعه حسينى نوده (Y|Y.Y) آزمون تحليل واريانس يككطرفه نشان داده كه بين تعداد فرزندان و نخرش
تفاوت مىتواند در تغييرات سريع علوم يزشكى نسبت به علوم كشاورزى و اين موضوع باشد كه نيروهاى داراى سابقه كار پيايينتر كه در واقع زمان كمترى از فارغالتحصيلى آنها كذشته است نسبت به ايمنى در محيط كارى خود داراى نخرش بالاتر هستند. رابطه بين مدركك تحصيلى افراد مورد مطالعه با نخرش

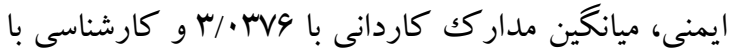
 مرتضوى (Y.19) رابطه كاركنان داراى تحصيلات دانشگاهى و نكرش ايمنى منفى و معنىدار ( 0/001) بوده است. به نظر مىرسد تأثير تحصيلات دانشگاهى بر نخرش ايمنى غيرقابل انكار است مىتوان كفت تحصيلات دانشخاهى در دوره فعلى، مىتواند نخرش ايمنى كار كنان را بهبود بخشد، هرجند كه با كذشت از زمان فراغت از تحصيلات دانشگاهى و ورود به محيط شغلى، نكرَ ش ايمنى افت مى كند. ميان سمت كاركنان فوريتهاى يزشكى و نخرش ايمنى تفاوت معنادارى ديده نشد. ولى مدير جانشين با ميانگين Y/VA

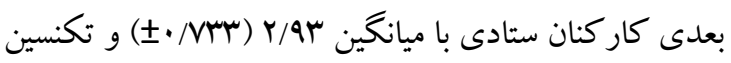

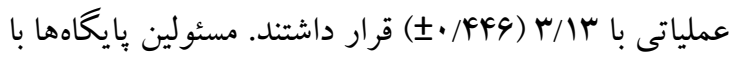

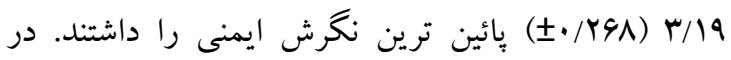
مطالعه اردشير و مهاجرى (Y) (Y. مدير يروزم، سريرست سايت و مدير اجرايى بالاترين و كارگران داراى كمترين سطح فرهنگ ايمنى بودند (Yr). مابين محل خدمت افراد موردمطالعه با نخرش ايمنى تفاوت معنادارى مشاهده نشد در عينحال كاركنان ستادى داراى نمره نخرش ايمنى بالاتر و كار كنان يايگاه جادهاى داراى نكرش ايمنى بايينترى بودند مىتوان نتيجه گرفت كه ارتباط بيشتر كاركنان ستادى با دستور العملها و بخشهاى مديريتى، سبب نكرش بالاى اين بخش از كاركنان به موضوع ايمنى هست. 
بيشترى آسيب ديده و ميزان تصادفات آمبولانسها بيشتر از وسايل نقليه مشابه خود هستند(YV). در مطالعه كنونى به دليل عدم ثبت و امكان بررسى اسناد و استخراج اطلاعات بر اساس اظهارات در يرسشنامها، محل تصادفات مشخص لئس نخرديد. اطلاعات موجود در كشورمان، تصادفات را بر اساس اندازه خودروها دستهبندى نكرده است و مقايسه آن با خودروى آمبولانس، امكانيذير نبود.

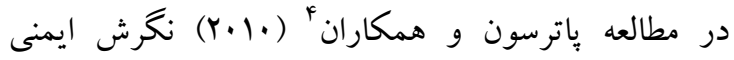
كار كنان فوريتهاى بزشكى ايالات ينسيلو انيا ايالات متحده در شش محور مشابه با مطالعه كنونى مورد سنجش قرار كرفته كه درك كاركنان از ايمنى بيمار در سطح بايينى بوده است. كمتر از نيمى از كاركنان دركك مثبى از جو دو دئه همكارى، وضعيت شغلى و شناخت استرس در محل كار

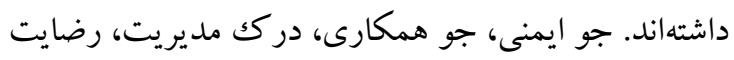
شغلى و وضعيت شغلى داراى تفاوت معنى دارى بوده است.

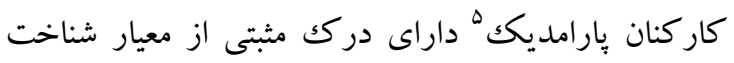
استرس بودهاند(YN). در مطالعه توصيفى ويور و و همكاران V (Y.11) انجام خرفته است خود اظهارى كار كنان فوريتهاى يز شكى داره

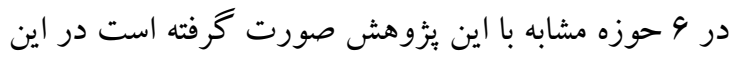
يُزوهش، با استفاده از برسشنامهاى توسعهيافنه، محورهاى

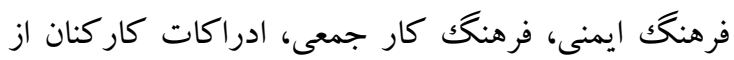

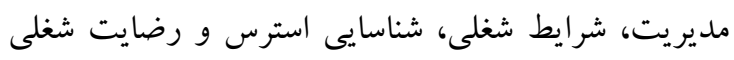
در مديران حوزه سلامت، تكنسينهاى فوريتهاى يزشكى و إيديميولوزيستها، ايمنى خدمات فوريتهاى يزشكى،

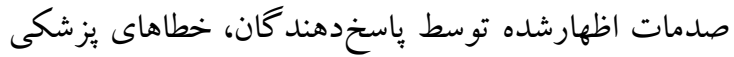
و عوارض جانبى و رفتارهاى سازش يافته ايمنى

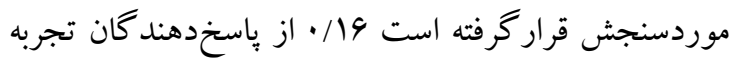
آسيب در طول ب ماه گذشته كارى خود را گزارش كرده بودند و از هر ·1 باسخدهنده \& نفر خطا يا عوارض جانبى و ها9/· رفتارهاى سازش يافته را گزارش كرده بودند(•(1).

\footnotetext{
${ }^{4}$ Daniel Patterson et al.

5 paramedic

${ }^{6}$ Matthew D. Weaver

${ }^{7}$ University of Pittsburgh
}

ايمنى به كار رابطه معنىدار وجود داشته است؛ و كار كنانى كه فرزندى نداشتند، نخرش ايمنى به كار مثبت ترى داشتهاند و بعد از اين گروه، افراد داراى بيش از دو فرزند، افراد داراى يكك فرزند و افراد داراى دو فرزند قرار داشتند. افراد داراى دو فرزند نخرش ايمنى مثبت ترى نسبت به كار كنان داراى يكك فرزند بودند كه در مطالعه كنونى عكس آن صادق بود(YD). تفاوت دو مطالعه مىتواند به تفاوت جنسيت جامعه نمونه دو يزوهش بر كردد. ميان فاصله محل سكونت با محل خدمت افراد موردمطالعه با نكرش ايمنى ارتباط معنادارى وجود نداشت. افراد داراى

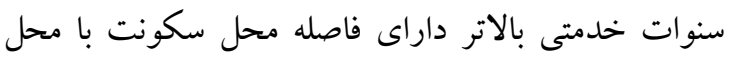
كارى كمترى بودند (ضريب همبستگى: ץ.ب/.•-) و معنادار نبود. در خصوص گز ارش خطاى منجر به آسيب به بيمار در

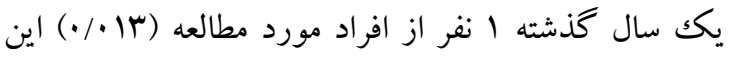
نوع از خطا را ذكر كرد اين نتيجه قابلتحليل نبود. ميان سابقه تصادف حين مأموريت در يكك سال گذشته در افراد

مو ردمطالعه و نخرش ايمنى رابطه معنادارى ديده نشد.

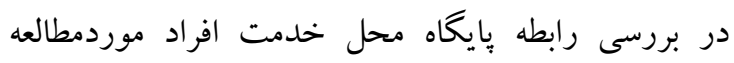
باسابقه تصادف آنها رابطه معنىدار بود و بيشترين ميزان

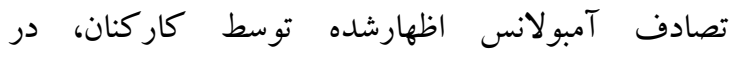
پايخاههاى شهرى بوده است؛ نبود خط عبورى ويزه خودروهاى امدادى در شهرهاى استان و سرعت بالاى اين خودروها در ترافيكك شهرى و در مأموريتهاى محوله، مىتواند دليلى براى اين موضوع باشد؛ هرجند كه محل

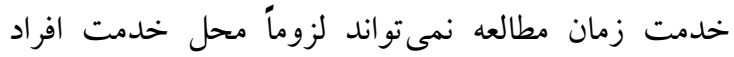

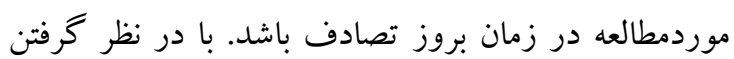
نسبت ا خودرو به س نفر جمعيت كشور(4) و تطابق اين

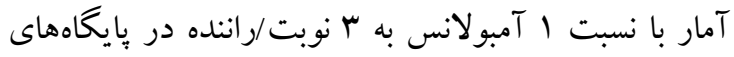
فوريتهاى بزشكى و با در نظر داشتن آمار سالانه ..1 هزار تصادف كشور نسبت به جمعيت كشور (1/٪) ميزان تصادف آمبولانس در جمعيت نمونه اين مطالعه، از ميانكين كشورى بالاتر است (II/•). در مطالعه آدام رى (ه.•(Y) اظهار شده كه تصادفات آمبولانس اغلب در تقاطعها و محل نصب سيكنالهاى جادهاى اتفاق مى افتد و افراد 
مطالعات مربوط به محيط اورزانس بيمارستانى است و با توجه به اهميت فراوان ايمنى كاركنان و بيماران در فوريتهاى يزشكى هاله، يُشنهاد مىشود مفاهيم مربوط به ايمنى در برنامهاى آموزشى كار كنان فوريتهاى بزشكى، كنجانده شود.

\section{تشكر و قدردانى}

مراتب تقدير و تشكر خود را از معاونت محترم تحقيقـات و

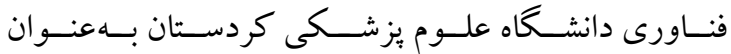
حمايت كننده مالى ابراز مىدارم. همجِنين از كار كنان محترم معاونست درمـان و مركـز مـديريت حسو ادث و فوريستهــاى يزشكى دانشكاه علوم بزشكى كردستان، كه من را در انجام اين بُزوهش كمكك كردند، تقدير و تشكر مىنمايم.
تفاوت فراوان اين دو خود اظهارى مىتواند به ذهنيت و يا تجربه نامناسب كادر بهداشت و درمان در فرهنگ خود اظهارى خطا و نحوه برخورد مديران با گزارش خطا باشد. در مطالعه زاليكا كلمنت ^ (Y.IV) معيارهاى ه كانه درك مديريت ، رضايت شغلى، جو ايمنى، جو كار تيمى و

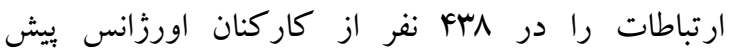
بيمارستانى كشور اسلونى " مورد بررسى قرار دادند كه جو كار تيمى داراى بالاترين ميانگين و رضايت شغلى داراى بايين ترين امتياز بود(Y). (Y). با توجه به اينكه در اين يزٔوهش كليه كاركنان ستادى و عملياتى با داشتن شرايط ورود به مطالعه مورد بررسى قرار كرفتند تعداد محدود يايگاههاى شهرى و جادهاى و تعداد بايين نمونهها، از محدوديتهاى اين مطالعه بود. علاوه بر آن پايگاههاى شهرى و جادهاى در ب نوبت كارى r نفره اداره مىشوند و در هر شيفت YF ساعته در پايگاه شهرى و

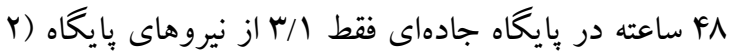
نفر از 4 نفر) حضور دارند كه براى هر پيايگاه ب نوبت مراجعه، در نظر گر فته شد.

\section{نتيجه كيرى}

نتايج مطالعه نشان داد كه نخرش ايمنى در كاركنان فوريتهاى يزشكى هال 11 شهرستان سنندج در سطح بايينى قرار دارد و نياز به آموزش و ارتقا دارد. هرجند كه بهجز مدرك تحصيلى و فاصله محل سكونت در ساير مشخصات فردى با معيارهاى شش گانه نگرش ايمنى، تفاوت معنادارى ديده نشد، ليكن در برخى متغيرها همجِون سمت، محل خدمت و وضعيت استخدامى، تفاوت در نكرش ايمنى وجود داشت كه مىتواند نقطه شروعى در بزوهشهاى بيشتر در اين زمينه باشد. تعداد يزوهشها و مطالعات در زمينه اورزانس بيش بيمارستانى در جهان بهطور كل و در كشورمان بهطور خاص، در سطح بِيينترى نسبت به

${ }^{8}$ Zalika Klemenc-Ketis

${ }^{9}$ Slovenian 


\section{References}

1. Aghababaeian H, Maniey M, Mazhin SA. The necessity of evaluating the stability of prehospital emergency service drugs in different climates. Iranian Journal of Emergency Medicine 2017;4:140-2.

2. Hohenstein C, Hempel D, Schultheis K, Lotter O, Fleischmann T. Critical incident reporting in emergency medicine: results of the prehospital reports. Emerg Med $\mathrm{J}$ 2014;31:415-8.

3. Tintinalli J. EMS: A Practical Global Handbook. Shelton: PMPH-USA; 2010.

4. Guise JM, Meckler G, O'Brien K, Curry M, Engle P, Dickinson C, et al. Patient safety perceptions in pediatric out-of-hospital emergency care: children's safety initiative. J Pediatr 2015;167:1143-8.

5. Bigham BL, Jensen JL, Tavares W, Drennan IR, Saleem H, Dainty KN, et al. Paramedic self-reported exposure to violence in the emergency medical services (EMS) workplace: A mixed-methods cross-sectional survey. Prehospital Emergency Care 2014; 18: 489-94.

6. Flin R. Measuring safety culture in healthcare: A case for accurate diagnosis. Saf Sci 2007;45:653-67.

7. Tourani S, Khodayari Zarnaq R, Arabloo J, Esmaili A, Taghizadeh S, Khosravizadeh O. A survey on patient safety using the farsi version of the safety attitudes questionnaire in Iran. $\mathrm{J}$ Payavard Salamat 2016;10:82-92.

8. Shirali G, Afravi M, Nezamodini ZS. Comparison between safety attitudes of CCU nurses in the educational and non-educational hospitals of Ahvaz. IOH 2016;12:89-97. [In Persian].

9. Ausserhofer D, Schubert M, Desmedt M, Blegen MA, De Geest S, Schwendimann R. The association of patient safety climate and nurse-related organizational factors with selected patient outcomes: a cross-sectional survey. Int J Nurs Stud 2013;50:240-52.

10. Weaver MD, Wang HE, Fairbanks RJ, Patterson D. The association between EMS workplace safety culture and safety outcomes. Prehosp Emerg Care 2012;16:43-52.

11. Hagiwara MA, Nilsson L, Strömsöe A, Axelsson C, Kängström A, Herlitz J. Patient safety and patient assessment in pre-hospital care: a study protocol. Scand J Trauma Resusc Emerg Med 2016;24:14.

12. Bayazidi S, Zarezadeh Y, Zamanzadeh V, Parvan K. Medication error reporting rate and its barriers and facilitators among nurses. J Caring Sci 2012;1:231-6.

13. Atkinson RL, Atkinson RC, Smith EE, Hilgard ER. Psychology. New York: American Book; 1987.

14. Jones D. Cambridge English pronouncing dictionary. Cambridge: Cambridge University Press; 2011.

15. Difference Between Attitude and Behavior [Internet]. Keydifferences. 2016 [cited 2018 Dec 21]. Available from: www.keydifferences.com.

16. Safaei P, Mohajer A, Jahed Khaniki GR. Thre attitude of food safety and hygiene students toward their field of study and future career in the Iranian Universities of medical sciences. sjsph. 2018;15:315-24.

17. Modak I, Sexton JB, Lux TR, Helmreich RL, Thomas EJ. Measuring safety culture in the ambulatory setting: The safety attitudes questionnaire-Ambulatory version. J Gen Intern Med 2007;22:1-5.

18. Siu OL, Phillips DR, Leung TW. Age differences in safety attitudes and safety performance in Hong Kong construction workers. J Safety Res 2003;34:199-205.

19. Rezaei MS, Golbabaei F, Behzadi MH. Assessing the healthcare workers' knowledge, attitude, and practice toward health, safety, and environment in an educational hospital 


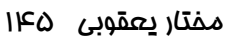

affiliated by Iran University of medical sciences (2012-2013). J Enviromental Sci Technol 2017; 19:347-55.

20. Karami GH, Bijani M, Salamat E. Investigating attitude toward safety isuues among agricultural Jihad professionals with an emphasis on safety training. J Heal Saf Work 2016;6:43-58.

21. Gharibi V, Mortazavi SB, Jafari AJ, Malakouti J, Abadi MBH. The Relationship between Workers' Attitude towards Safety and Occupational Accidents Experience. Int J Occup Hyg 2017;8:145-50.

22. Ardeshir A, Mohajeri M. Assessment of safety culture among job positions in high-rise construction: a hybrid fuzzy multi criteria decision-making (FMCDM) approach. Int J Inj Contr Saf Promot 2018;25:195-206.

23. Amini M, Alimohammadi I, Jahanihashemi H, Yakke Fallah D. The relationship between the prevalence of accidents and safety culture in two detergents and cleaners Companies in 1391. Iran Occup Heal 2013;10:93-105.

24. Ghahramani A, Fazli B. An investigation of safety attitude in a number of manufacturing companies in Urmia. Heal Saf Work 2016;6:41-50.

25. Hosaini M, Hosaini Nude Z, Yaghmai F, Alawi Majd H, Jabari M. Study of correlation between demographic characteristics and safety attitudes in women workers in food factory. Heal Promot Manag 2012;1:64-72.

26. Salimi Bani O. Road accidents in Iran, one and a half times the global average [Internet]. 2013 [cited 2018 Dec 7]. Available from: www.khabaronline.ir. [In persian]

27. Ray AF, Kupas DF. Comparison of crashes involving ambulances with those of similarsized vehicles. Prehospital Emerg Care 2005;9:412-5.

28. Patterson PD, Huang DT, Fairbanks RJ, Wang HE. The emergency medical services safety attitudes questionnaire. Am J Med Qual 2010;25:109-15.

29. Klemenc-Ketis Z, Maletic M, Stropnik V, Deilkås ET, Hofoss D. The safety attitudes questionnaire - ambulatory version : psychometric properties of the Slovenian version for the out-of-hours primary care setting. BMC Health Serv Res 2017; 17: 36. 